\title{
Brood size and its importance for nestling growth in the Biscutate Swift (Streptoprocne biscutata, Aves: Apodidae)
}

\author{
Pichorim, M. ${ }^{\mathrm{a} *}$ and Monteiro-Filho, ELA. ${ }^{\mathrm{b}}$ \\ ${ }^{a}$ Departamento de Botânica, Ecologia e Zoologia, Centro de Biociências, Campus Universitário, \\ Universidade Federal do Rio Grande do Norte - UFRN, \\ CEP 59072-970, Natal, RN, Brazil \\ bDepartamento de Zoologia, Centro Politécnico, Universidade Federal do Paraná - UFPR, \\ CP 19020, CEP 81531-990, Curitiba, PR, Brazil \\ *e-mail: mauropichorim@yahoo.com.br
}

Received December 22, 2006 - Accepted June 14, 2007 - Distributed November 30, 2008

(With 1 figure)

\begin{abstract}
Many Apodidae, including Streptoprocne biscutata (Sclater, 1866), drop eggs from their nests during incubation. This is interpreted as nest site competition or accident. We provide evidence that egg ejection is deliberate and that this behaviour controls the brood size. Brood sizes were manipulated and nestling growth was measured to test the hypothesis that pairs can regulate brood size during incubation based on current ability to rear nestlings. Natural (control) broods with one, two and three nestlings, and manipulated (experimental) broods reduced to one and increased to two and three young were monitored. Growth rates were measured based on weight, and wing, tail and tarsus lengths of natural and manipulated broods. We compared the slopes of each measure's regression lines of the nestlings of each brood size by $t$-test. Nestling growth of control nests was similar and relatively little associated with brood size. In broods reduced to one nestling, weight, wing and tail had greater growth rates, and in broods increased to three nestlings growth rates were lower. Weight was most, and tarsus length least influenced by brood size. In general, nestling growth of manipulated nests was inversely proportional to brood size. The results suggest that pairs with larger clutches are in better physical conditions than others. Thus, in experimental broods, pairs are over or under-loaded because feeding activities increase or decrease and these changes affect the growth rate of the nestlings. The present study suggests that egg ejection can control brood size. This behaviour is probably stimulated by physical changes in the adult birds during incubation.
\end{abstract}

Keywords: nestling growth, brood manipulation, brood reduction, incubation.

\section{Tamanho da ninhada e sua importância no crescimento de filhotes de Streptoprocne biscutata (Aves: Apodidae)}

\begin{abstract}
Resumo
Muitos Apodidae, incluindo Streptoprocne biscutata (Sclater, 1866), derrubam ovos do ninho durante a incubação. Este comportamento tem sido interpretado como competição ou acidente. Este estudo apresenta evidências de que a expulsão de ovos é deliberada e que esse comportamento controla o tamanho da ninhada. Ninhos com diferentes tamanhos de prole foram manipulados para testar a hipótese de que os casais podem regular o tamanho da ninhada durante a incubação com base em suas capacidades de alimentar os filhotes. Ninhadas naturais (controle) com um, dois e três filhotes e ninhadas manipuladas (experimentais) reduzidas para um e aumentadas para dois e três filhotes foram monitoradas. Foram medidas as taxas de crescimento de massa, asa, cauda e tarso de proles naturais e manipuladas. As inclinações das retas de regressão do desenvolvimento de cada medida ao longo da idade dos filhotes de cada tamanho de ninhada foram comparadas pelo $t$-teste. $\mathrm{O}$ crescimento dos filhotes de ninhos controle foi semelhante e esteve relativamente pouco associado ao tamanho da ninhada. Nas ninhadas reduzidas para um filhote, a massa, asa e cauda apresentaram as maiores taxas de crescimento e nas ninhadas aumentadas para três filhotes ocorreram as menores taxas. A massa foi a variável mais influenciada pelos experimentos e o tarso a menos. De forma geral, o crescimento dos filhotes de ninhos manipulados foi inversamente proporcional ao tamanho da ninhada. Os resultados sugerem que os casais com mais filhotes estão em melhores condições físicas do que os outros. Por isso, nas ninhadas experimentais, a taxa de crescimento dos filhotes muda em virtude dos casais se encontrarem sub ou sobrecarregados na tarefa de alimentação. Sugere-se que o comportamento de expulsão de ovos possa ser uma forma de regular o tamanho da ninhada, o qual provavelmente é desencadeado por mudanças nas condições físicas das aves adultas durante o período de incubação.
\end{abstract}

Palavras-chave: crescimento de filhotes, manipulação de ninhadas, redução de ninhadas, incubação. 


\section{Introduction}

Apodidae are generally classified as altricial or nidicolous with regard to their post-embryonic development (Chantler and Driessens, 1995). This development pattern is characterised by the fact that nestlings are born naked and depend strongly upon parents. The family presents strong interspecific variation in brood size, in spite of the common development pattern in which participation of the parents is strongly required. This somehow evidences that some species manage to optimize their performance in food seizure thus creating a larger brood. Clutch-size varies in the family from one to seven eggs, whilst smaller clutches belong to larger-sized species, principally Cypseloides and Streptoprocne (Chantler and Driessens, 1995; Chantler, 1999). Until recently, it was believed that in these genera, clutch-size is very much conserved and strongly ruled by a genetic component (Chantler, 1999). Current initial studies indicate, however, that at least in Streptoprocne sporadically larger clutches occur than usual, reaching up to four eggs, although two is commonest (Pichorim, 1998; Vasconcelos and Ferreira, 2001; Pichorim, 2002). These brood-sizes can be related to environmental variables and, consequently, to physical conditions of some females. This suggests that females in better condition would lay more eggs, although no more than two are incubated until hatching (Pichorim, 1998; Pichorim, 2002). This implies that during incubation some eggs are expelled from the nest and only one or two young are created. It has been contemplated that this behaviour, in principle, could be related to environmentally based changes of physical conditions taking place from egg-laying until the end of incubation (Pichorim, 2003). According to this hypothesis, females in good physical condition in the period before egg-laying would lay more eggs, but couples that go through some kind of difficulty during the incubation would tend to exclude part of the brood, reducing the number of young to be reared (Pichorim, 2003). This means that environmental changes would unleash some kind of stress behaviour culminating in egg ejection. That would make the number of young to be reared compatible with the couple's current physical capacity. Thus, this paper aims to investigate if brood size is related to the parents' capacity to feed the brood.

\section{Material and Methods}

The study was carried out from 1999 to 2001 in Vila Velha State Park, in the municipality of Ponta Grossa, state of Paraná, southern Brazil ( $25^{\circ} 15^{\prime} \mathrm{S}$ and $50^{\circ} 00^{\prime} \mathrm{W}$, circa $1,000 \mathrm{~m}$ above sea level). It is located at $80 \mathrm{~km}$ from Curitiba and at $20 \mathrm{~km}$ from Ponta Grossa, in a region covered with grassy woody steppe and small plots of Rain Forest with Araucaria angustifolia (Bert) O. Ktze. The studied colony occupies a sandstone formation and consists of several rocky fissures distributed over an area of approximately 5 ha. The dimensions of the fissures used by birds vary a lot. In general they are 10 to $30 \mathrm{~m}$ high, 10 to $60 \mathrm{~m}$ long and 0.5 to $8 \mathrm{~m}$ broad. The walls are vertical and humid in the parts occupied by birds, but water drips only during rain or immediately afterwards. Some specimens of Streptoprocne zonaris (Shaw, 1796) appear at this place sporadically. In the region there occurs a warm and rainy spring and summer and a cold winter occasionally with dry periods, characterized as the ' $\mathrm{Cfb}$ ' type of climate classification of W.P. Köppen and R. Geiger (Maack, 1968).

The development of nestlings in nests suffering change of brood size was accompanied to compare physical conditions of couples with broods of different size. We tested the null hypothesis that the rate of nestling growth in a brood size is independent from the nest where they develop. To achieve this, we changed broods between nests with one and two young and we accompanied their development. In other nests we either reduced or increased their broods.

To implement the tests, we surveyed all nests of the study area during the periods of nest construction and egg-laying in each reproductive season. We registered the number of laid eggs and the number of born young for each nest. Next, we changed the brood of nests with two nestlings with that of nests with one nestling. After this change, we monitored the growth of the nestlings until they left the nests. Nestlings of non-manipulated nests with broods of one and two were measured as control.

To test the influence of brood size upon nestlings' growth in extreme conditions, we added one nestling in nests with a brood of two, to verify the capacity of the birds to feed a brood of untypical size $(n=3)$. The additional young had similar age (weight and dimensions) than those already in the nest.

In all nests monitored we measured nestlings with regard to weight, length of tail, tarsus and flattened wing, in intervals varying from three to seven days. Only nestlings aged between four and seven days were involved in changes of brood between nests.

We compared the development of nestlings between brood sizes through a simple linear regression of the measured data regarding age. Only linear period of growth of each structure was considered for the analyses. We used a $t$-test (in agreement with Zar, 1984) to compare the angular coefficients of each regression to test the null hypothesis of equality of inclination of the regression lines between treatments. Also, with the measured variables (weight, wing, tail and tarsus), we applied a principal components analysis on correlation to obtain the component one (PC1). We compared the inclination of the regression line of the $\mathrm{PC} 1$ between the treatments with a $t$-test. Tests were applied by using the program JMP 4.0.4 adopting alpha $=0.05$.

Nestlings were measured with a caliper of $15 \mathrm{~cm}$ and a ruler of $30 \mathrm{~cm}$, both metallic and with a precision of $0.05 \mathrm{~mm}$. Weight was obtained with Pesola spring balances (50, 100 and $300 \mathrm{~g}$ ) (precision 0.1, 0.25 and $1 \mathrm{~g}$ ). The following abbreviations have been adopted in the 
text: control brood size equal to one $(\mathrm{CBS}=1)$; control brood size equal to two $(\mathrm{CBS}=2)$; control brood size equal to three $(\mathrm{CBS}=3)$, experimental brood size equal to one $(\mathrm{EBS}=1)$, experimental brood size equal to two $($ EBS $=2)$ and experimental brood size equal to three $(\mathrm{EBS}=3)$. The nomenclature and taxonomic sequence of the cited species follow Chantler (1999).

\section{Results}

\subsection{Weight}

During the period of 9 to 24 days of life nestlings of nests with control brood size equal to one, two and three had a similar weight gain. In this period we accompanied nine nestlings of nests with $\mathrm{CBS}=1$, for which $82 \%$ of the weight variation occurred in function of age $\left(\right.$ Weight $_{\mathrm{CBS}=1}=33.1+4.73$ Age; $\mathrm{r}^{2}=0.82 ; \mathrm{F}_{1,50}=220.3$; $\mathrm{P}<0.05)$. In nests with $\mathrm{CBS}=2$ we accompanied 26 nestlings, in which $80 \%$ of the weight variation occurred in function of age $\left(\right.$ Weight $_{\mathrm{CBS}=2}=11.7+5.61$ Age; $\left.\mathrm{r}^{2}=0.80 ; \mathrm{F}_{1,102}=414.0 ; \mathrm{P}<0.05\right)$. The nestlings in two nests with CBS $=3$ showed $79 \%$ of weight variation in function of age $\left(\right.$ Weight $_{\mathrm{CBS}=3}=-5.5+4.73 \mathrm{Age} ; \mathrm{r}^{2}=0.79$; $\left.\mathrm{F}_{1,4}=15.1 ; \mathrm{P}<0.05\right)$.

The nestlings of nests with EBS showed some differences in the regressions for the period of 9 to 24 days of life. In 10 nests with EBS $=1,82 \%$ of the weight variation of the nestlings occurred in function of age $\left(\right.$ Weight $_{\mathrm{EBS}=1}=7.1+6.12$ Age; $\mathrm{r}^{2}=0.82$; $\left.\mathrm{F}_{1,36}=169.5 ; \mathrm{P}<0.05\right)$. In nine nests with $\mathrm{EBS}=2$, $79 \%$ of the weight variation of the nestlings resulted from age $\left(\right.$ Weight $_{\mathrm{EBS}=2}=20.2+4.67$ Age; $\mathrm{r}^{2}=0.79$; $\left.\mathrm{F}_{1,66}=245.4 ; \mathrm{P}<0.05\right)$. In three nests with $\mathrm{EBS}=3,69 \%$ of the weight variation of the nestlings resulted from age $\left(\right.$ Weight $_{\mathrm{EBS}=3}=18.1+3.02$ Age; $\mathrm{r}^{2}=0.69 ; \mathrm{F}_{1,14}=31.1$; $\mathrm{P}<0.05)$.

The daily rates of weight increment (represented by angular coefficients of the regressions) were different between some treatments (Table 1). The largest rate occurred for nests with EBS = 1 (6.12 g per day) and the smallest for nests with EBS $=3$ (3.02 g per day). The rate for nestlings of nests with $\mathrm{CBS}=2$ was larger than that of nests with $\mathrm{EBS}=2$ and $\mathrm{CBS}=1$ (5.61 g per day against $4.67 \mathrm{~g}$ per day and $4.73 \mathrm{~g}$ per day respectively) (Table 1). The rate of $4.73 \mathrm{~g}$ per day for nests with $\mathrm{CBS}=3$ was elevated and did not differ from the rate of the other treatments (Table 1, Figure 1).

\subsection{Wing}

During the period of 8 to 28 days of life nestlings of nests with control and experimental broods equal to one, two and three showed few differences in the wing growth. In this period we accompanied nine nestlings of nests with CBS $=1$, for which $98 \%$ of wing variation depended upon age $\left(\right.$ Wing $_{\mathrm{CBS}=1}=-11.9+5.13$ Age; $\left.\mathrm{r}^{2}=0.98 ; \mathrm{F}_{1,32}=1667,4 ; \mathrm{P}<0.05\right)$. In nests with $\mathrm{CBS}=2$ we accompanied 32 nestlings, in which $97 \%$ of wing variation occurred in function of age $\left(\right.$ Wing $_{\mathrm{CBS}=2}=-17.3+$
5.25 Age; $\left.\mathrm{r}^{2}=0.97 ; \mathrm{F}_{1,70}=2036.5 ; \mathrm{P}<0.05\right)$. The nestlings in two nests with CBS $=3$ showed $95 \%$ of wing variation in function of age $\left(\right.$ Wing $_{\mathrm{CBS}=3}=-19.5+$ 4.93 Age; $\left.\mathrm{r}^{2}=0.95 ; \mathrm{F}_{1,4}=83.8 ; \mathrm{P}<0.05\right)$. In 12 nests with $\mathrm{EBS}=1,95 \%$ of wing variation occurred in function of age $\left(\right.$ Wing $_{\mathrm{EBS}=1}=-20.2+5.51$ Age; $\left.\mathrm{r}^{2}=0.95 ; \mathrm{F}_{1,32}=663.8 ; \mathrm{P}<0.05\right)$. In 10 nests with $\mathrm{EBS}=2,98 \%$ of the wing variation of nestlings resulted from age $\left(\right.$ Wing $_{\mathrm{EBS}=2}=-13.5+5.16$ Age; $\mathrm{r}^{2}=0.98$; $\left.\mathrm{F}_{1,64}=4102.2 ; \mathrm{P}<0.05\right)$. And, in three nests with $\mathrm{EBS}=3,95 \%$ of the wing variation resulted from age $\left(\right.$ Wing $_{\mathrm{EBS}=3}=-15.4+4.51$ Age $; \mathrm{r}^{2}=0.95 ; \mathrm{F}_{1,16}=316.3$; $\mathrm{P}<0.05)$.

The daily rates of wing growth showed little difference between treatments (Table 1). We observed the largest rate in nests with EBS $=1(5.51 \mathrm{~mm}$ per day $)$. It was statistically different from rates of nestlings of nests with $\mathrm{EBS}=2$ (5.15 $\mathrm{mm}$ per day) and EBS $=3(4.51 \mathrm{~mm}$ per day) (Table 1, Figure 1). The wing growth rate of nests with EBS = 3 (the smallest observed) was statistically different from all other nests, except of nets with $\mathrm{CBS}=3$ (4.93 mm per day) $($ Table 1 , Figure 1$)$

\subsection{Tail}

During the period of 13 to 32 days of life we accompanied nine nests with CBS $=1$, for which $97 \%$ of tail growth depended upon age (Tail $_{\mathrm{CBS}=1}=-26.3+$ 2.57 Age; $\left.\mathrm{r}^{2}=0.97 ; \mathrm{F}_{1,23}=694.2 ; \mathrm{P}<0.05\right)$. In 15 nests with CBS $=2$ we observed $95 \%$ of tail variation in function of age (Tail $_{\mathrm{CBS}=2}=-28.1+2.54$ Age; $\mathrm{r}^{2}=0.95$; $\left.\mathrm{F}_{1,77}=1404.6 ; \mathrm{P}<0.05\right)$. In this period, we did not accompany the tail growth in nests with $\mathrm{CBS}=3$, but for EBS we follow nests with one, two and three nestlings. In 11 nests with $\mathrm{EBS}=1,95 \%$ of tail variation occurred in function of age (Tail $_{\mathrm{EBS}=1}=-28.7+2.68$ Age; $\mathrm{r}^{2}=0.95$; $\left.\mathrm{F}_{1,27}=494.2 ; \mathrm{P}<0.05\right)$. In 10 nests with $\mathrm{EBS}=2,97 \%$ of tail variation resulted from age $\left(\right.$ Tail $_{\mathrm{EBS}=2}=-26.1+$ 2.55 Age; $\left.\mathrm{r}^{2}=0.97 ; \mathrm{F}_{1,47}=1597.2 ; \mathrm{P}<0.05\right)$. In three nests with $\mathrm{EBS}=3,88 \%$ of tail variation resulted from age $\left(\right.$ Tail $_{\mathrm{EBS}=3}=-17.7+1.75$ Age; $\mathrm{r}^{2}=0.88 ; \mathrm{F}_{1,16}=70.6$; $\mathrm{P}<0.05)$.

The daily rates of tail growth were similar between treatments (Table 1). We observed the largest rate in nests with $\mathrm{EBS}=1$ (2.68 $\mathrm{mm}$ per day). It was statistically different only for the rate of nests with EBS $=3(1.74 \mathrm{~mm}$ per day - the lowest), which was different from all others (Table 1, Figure 1).

\subsection{Tarsus}

During the period of 4 to 16 days of life we accompanied six nests with $\mathrm{CBS}=1$, for which $93 \%$ of tarsus growth depended upon age (Tarsus $_{\mathrm{CBS}=1}=12.2+$ 0.85 Age $\left.\mathrm{r}^{2}=0.93 ; \mathrm{F}_{1,12}=152.3 ; \mathrm{P}<0.05\right)$. In 13 nests with $\mathrm{CBS}=2$ we observed $87 \%$ of tarsus variation in function of age (Tarsus $_{\mathrm{CBS}=2}=12.1+0.83 \mathrm{Age} ; \mathrm{r}^{2}=0.87$; $\left.\mathrm{F}_{1,88}=598.4 ; \mathrm{P}<0.05\right)$. In this period, we did not accompany the tarsus growth in nests with $\mathrm{CBS}=3$, but for EBS we follow nests with one, two and three nestlings. In 

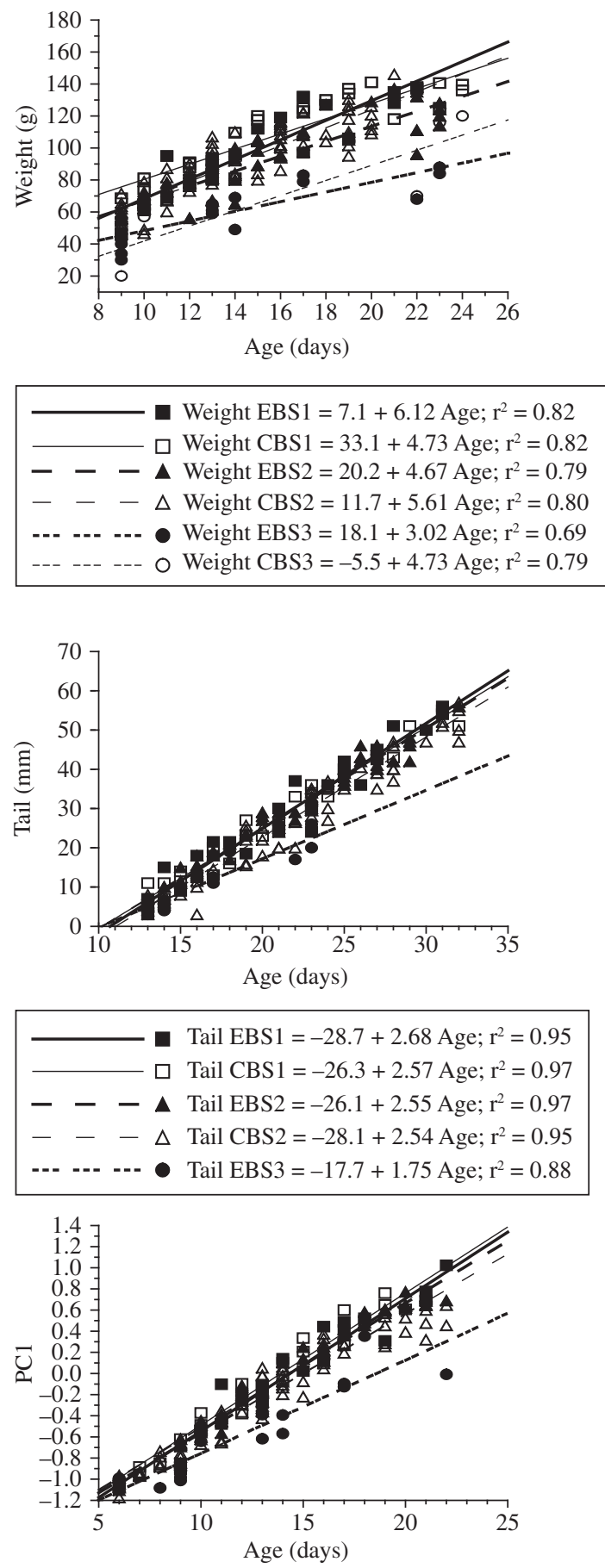

Figure 1. Regression lines of weight, wing, tail, tarsus and principal component 1 (PC1) in relation to age of Streptoprocne biscutata nestlings from nests with control and experimental brood sizes (CBS and EBS) equal to one, two and three observed in southern Brazil.

12 nests with $\mathrm{EBS}=1,90 \%$ of tarsus variation depended upon age (Tarsus $_{\mathrm{EBS}=1}=13.3+0.79$ Age; $\mathrm{r}^{2}=0.90$; $\left.\mathrm{F}_{1,17}=153.7 ; \mathrm{P}<0.05\right)$. In 10 nests with $\mathrm{EBS}=2,94 \%$ of tarsus variation resulted from age Tarsus $_{\mathrm{EBS}=2}=13.2+$ 0.81 Age $\left.r^{2}=0.94 ; F_{1,33}=494.4 ; P<0.05\right)$. In three nests
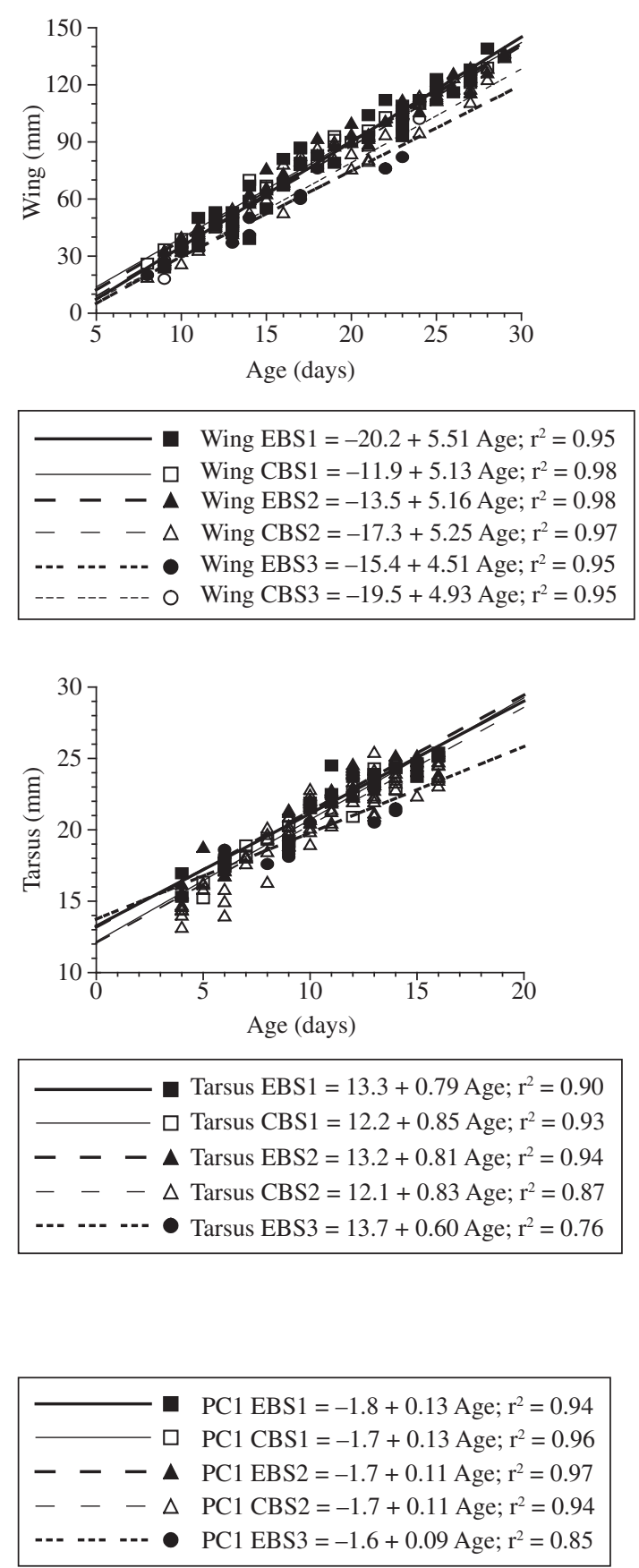

with $\mathrm{EBS}=3,76 \%$ of tarsus variation resulted from age Tarsus $_{\mathrm{EBS}=3}=13.7+0.60$ Age $; \mathrm{r}^{2}=0.76 ; \mathrm{F}_{1,13}=40.7$; $\mathrm{P}<0.05)$.

The daily rates of tarsus growth were similar between treatments (Table 1). We observed the largest rate 
Table 1. Comparison between rates of growth (angular coefficients of regression line) of Streptoprocne biscutata nestlings from nests with different brood sizes observed in southern Brazil.

\begin{tabular}{|c|c|c|c|c|c|}
\hline \multirow[t]{2}{*}{$\begin{array}{l}\text { Control and experimental } \\
\text { brood sizes (CBS and EBS) }\end{array}$} & \multicolumn{5}{|c|}{$\begin{array}{c}t \text {-values, df and respective rates of growth of each } \\
\text { measurement in the treatments compared }\end{array}$} \\
\hline & $\begin{array}{c}\text { Weight } \\
(9-24 \text { days })^{b}\end{array}$ & $\begin{array}{c}\text { Wing } \\
(8-24 \text { days })^{b}\end{array}$ & $\begin{array}{c}\text { Tail } \\
(13-32 \text { days })^{b}\end{array}$ & $\begin{array}{c}\text { Tarsus } \\
(4-16 \text { days })^{b}\end{array}$ & $\begin{array}{c}\text { PC1 }^{\mathrm{a}} \\
\left(6-22 \text { days }^{\mathrm{b}}\right.\end{array}$ \\
\hline \multirow[t]{2}{*}{$\mathrm{EBS}=1 \times \mathrm{CBS}=1$} & $2.49^{c} ; 86$ & $1.48 ; 62$ & $0.71 ; 50$ & $0.68 ; 29$ & $0.05 ; 42$ \\
\hline & $6.12 ; 4.73$ & $5.51 ; 5.13$ & $2.68 ; 2.57$ & $0.79 ; 0.85$ & $0.13 ; 0.13$ \\
\hline \multirow[t]{2}{*}{$\mathrm{EBS}=1 \times \mathrm{EBS}=2$} & $\mathbf{2 . 6 1} ; 102$ & 1.74c; 96 & $1.04 ; 74$ & $0.36 ; 50$ & $1.2 ; 64$ \\
\hline & $6.12 ; 4.67$ & $5.51 ; 5.16$ & $2.68 ; 2.55$ & $0.79 ; 0.81$ & $0.13 ; 0.11$ \\
\hline \multirow[t]{2}{*}{$\mathrm{EBS}=1 \times \mathrm{CBS}=2$} & $1.0 ; 138$ & $1.14 ; 102$ & $1.01 ; 104$ & $0.46 ; 105$ & $1.93 ; 118$ \\
\hline & $6.12 ; 5.61$ & $5.51 ; 5.25$ & $2.68 ; 2.54$ & $0.79 ; 0.83$ & $0.13 ; 0.11$ \\
\hline \multirow[t]{2}{*}{$\mathrm{EBS}=1 \times \mathrm{EBS}=3$} & 4.18 $; 50$ & $\mathbf{2 . 5 8}$ c $; 48$ & 3.32' $; 37$ & $1.63 ; 30$ & $\mathbf{3 . 4 5}^{\text {c }} ; 39$ \\
\hline & $6.12 ; 3.02$ & $5.51 ; 4.51$ & $2.68 ; 1.74$ & $0.79 ; 0.60$ & $0.13 ; 0.09$ \\
\hline \multirow[t]{2}{*}{$\mathrm{EBS}=1 \times \mathrm{CBS}=3$} & $1.52 ; 40$ & $1.14 ; 36$ & $-d$ & $-d$ & $-d$ \\
\hline & $6.12 ; 4.73$ & $5.51 ; 4.93$ & & & \\
\hline \multirow[t]{2}{*}{$\mathrm{CBS}=1 \times \mathrm{EBS}=2$} & $0.14 ; 116$ & $0.19 ; 94$ & $0.15 ; 70$ & $0.56 ; 45$ & $1.15 ; 62$ \\
\hline & $4.73 ; 4.67$ & $5.13 ; 5.16$ & $2.57 ; 2.55$ & $0.85 ; 0.81$ & $0.13 ; 0.11$ \\
\hline \multirow[t]{2}{*}{$\mathrm{CBS}=1 \times \mathrm{CBS}=2$} & $\mathbf{2 . 1 2} \mathbf{2}^{\mathrm{c}} ; 152$ & $0.58 ; 100$ & $0.17 ; 100$ & $0.3 ; 100$ & $1.75 ; 116$ \\
\hline & $4.73 ; 5.61$ & $5.13 ; 5.25$ & $2.57 ; 2.54$ & $0.85 ; 0.83$ & $0.13 ; 0.11$ \\
\hline \multirow[t]{2}{*}{$\mathrm{CBS}=1 \times \mathrm{EBS}=3$} & $2.69^{\text {c }} ; 64$ & $2.37^{\text {c }} ; 46$ & $\mathbf{3 . 5 5}$ c; 33 & $\mathbf{2 . 1 4}$ c $; 25$ & $\mathbf{3 . 5 1} 1^{\mathrm{c}} ; 37$ \\
\hline & $4.73 ; 3.02$ & $5.13 ; 4.51$ & $2.57 ; 1.74$ & $0.85 ; 0.60$ & $0.13 ; 0.09$ \\
\hline \multirow{2}{*}{$\mathrm{CBS}=1 \times \mathrm{CBS}=3$} & $0.01 ; 54$ & $0.61 ; 34$ & $-\mathrm{d}$ & $-d$ & $-\mathrm{d}$ \\
\hline & $4.73 ; 4.73$ & $5.13 ; 4.93$ & & & \\
\hline \multirow[t]{2}{*}{$\mathrm{EBS}=2 \times \mathrm{CBS}=2$} & $\mathbf{2 . 3 5} ; 168$ & $0.57 ; 134$ & $0.06 ; 124$ & $0.21 ; 121$ & $1.01 ; 138$ \\
\hline & $4.67 ; 5.61$ & $5.16 ; 5.25$ & $2.55 ; 2.54$ & $0.81 ; 0.83$ & $0.11 ; 0.11$ \\
\hline \multirow[t]{2}{*}{$\mathrm{EBS}=2 \times \mathrm{EBS}=3$} & $2.5^{c} ; 80$ & $\mathbf{2 , 6 5} ; 80$ & $4.2^{\mathrm{c}} ; 57$ & $2.39^{c} ; 46$ & 3.9c $; 59$ \\
\hline & $4.67 ; 3.02$ & $5.16 ; 4.51$ & $2.55 ; 1.74$ & $0.81 ; 0.60$ & $0.11 ; 0.09$ \\
\hline \multirow[t]{2}{*}{$\mathrm{EBS}=2 \times \mathrm{CBS}=3$} & $0.08 ; 70$ & $0.76 ; 68$ & $-\mathrm{d}$ & $-d$ & $-\mathrm{d}$ \\
\hline & $4.67 ; 4.73$ & $5.16 ; 4.93$ & & & \\
\hline \multirow[t]{2}{*}{$\mathrm{CBS}=2 \times \mathrm{EBS}=3$} & $\mathbf{4 . 4 4} ; 116$ & $\mathbf{2 . 3 6} 6^{\mathrm{c}} ; 86$ & 3.1 $; 87$ & $\mathbf{2 . 0 1} \mathbf{1}^{\mathrm{c}} ; 101$ & 3.29c; 113 \\
\hline & $5.61 ; 3.02$ & $5.25 ; 4.51$ & $2.54 ; 1.74$ & $0.83 ; 0.60$ & $0.11 ; 0.09$ \\
\hline \multirow[t]{2}{*}{$\mathrm{CBS}=2 \times \mathrm{CBS}=3$} & $1.3 ; 106$ & $0.81 ; 74$ & $-d$ & $-d$ & $-\mathrm{d}$ \\
\hline & $5.61 ; 4.73$ & $5.25 ; 4.93$ & & & \\
\hline \multirow[t]{2}{*}{$\mathrm{EBS}=3 \times \mathrm{CBS}=3$} & $1.62 ; 18$ & $0.89 ; 20$ & $-d$ & $-d$ & $-\mathrm{d}$ \\
\hline & $3.02 ; 4.73$ & $4.51 ; 4.93$ & & & \\
\hline
\end{tabular}

aPrincipal component 1, obtained by a Principal Component Analysis - PCA on correlation between the measures of weight,

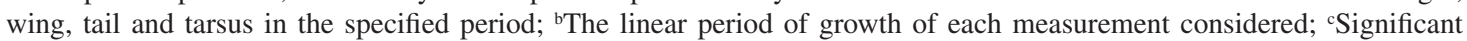
$t$-values $(\mathrm{P}<0.05)$; and ${ }^{\mathrm{d}} \mathrm{We}$ did not accompany nests with $\mathrm{CBS}=3$ for the respective measurement.

in nests with $\mathrm{CBS}=1(0.85 \mathrm{~mm}$ per day $)$. We found the smallest one for nests with EBS $=3(0.60 \mathrm{~mm}$ per day), which was statistically different from the rate of nests with $\mathrm{CBS}=1, \mathrm{CBS}=2$ and $\mathrm{EBS}=2$ (Table 1 , Figure 1).

\subsection{Principal component one}

The analysis of principal components showed that component one (PC1) responded for $89.6 \%$ of variation of weight, wing, tail and tarsus. By regression of the PC1 between 6 and 22 days of life (the larger linearity period), we found few differences in rates of growth between treatments (Table 1, Figure 1). In nests with EBS = 3 the PC1 depended less from age when compared with other treatments. Besides, the angular coefficient of the regression for nests with EBS = 3 was distinctly lower (Table 1, Figure 1).

\section{Discussion}

Rates of weight gain and growth of wing, tail and tarsus were similar in the control nests. The brood size did not influence the development of nestlings in these nests. These results suggest that some couples manage 
to raise a larger brood without loss of quality in the development of the nestlings. This capacity was also related for other species, as in Apus apus (Linnaeus, 1758) where nestlings of natural broods of different sizes do not show substantial differences in the weight gain during development (Pellantová, 1981), and for Aerodramus fuciphagus (Thunberg, 1812), where the weight and growth of wing also vary little between broods of different sizes (Langham, 1980).

For weight we observed a little deviation of this tendency in nests with $\mathrm{CBS}=2$, where the daily gain was significantly larger in relation to nests with $\mathrm{CBS}=1$. In this case the results could somehow indicate that couples with less raising capacity or still without experience tend to have smaller brood sizes to obtain a larger probability of success, but even then their nestlings do not develop as quick than those of couples with brood size equal two, which probably have better conditions or more experience. We know that reproductive success in S. biscutata during the period of the brood's development is inversely related to the number of young to be reared (Pichorim, 2003). Couples of A. apus lay fewer eggs when they face their first reproductive period (Lack and Lack, 1951). The same occurs in Chaetura pelagica (Linnaeus, 1758) and Tachymarptis melba (Linnaeus, 1758) (Lack and Arn, 1947; Dexter, 1981). Maybe the inexperience of couples exerts pressure upon clutch size, as seen in the cases above, as well as upon the young's speed of growth.

We observed in manipulated nests that rates of growth were not similar between the different sizes of broods. Although some values are not statistically different, weight, wing and tail of the young of nests with $\mathrm{EBS}=1$ had a larger daily growth than in the young of other brood sizes. In a similar way, but inversely, nests with EBS $=3$ had the smallest rate of growth. For principal component one, which summarizes the analysed morphological variation, this tendency was rather discrete but visible. In Aerodramus spodiopygius (Peale, 1848) nestlings of reduced broods for one showed both a quicker weight gain and wing growth than nestlings of broods equal to two or three, and broods increased to three had the smallest growth rates (Tarburton, 1987). As demonstrated above, we observed in S. biscutata a quite similar result. In broods of Cypseloides niger (Gmelin, 1789) increased to two, the nestlings compete for resources, and one bird developed slower than the other one with regard to weight, wing and tail (Marín, 1997). Increased broods of $A$. apus also produced lighter young than reduced broods (Martins and Wright, 1993).

With regard to the measures analysed in the experiments we observed that weight was most influenced by the treatments and tarsus growth least. This tendency was observed in other experiments with brood manipulation in swifts (Tarburton, 1987; Cucco and Malacarne, 1996; Marín 1997). Apparently, the dimensions of nestlings taken as a whole are quite well conserved in conditions of alimentary stress, but the fat reserves are affected.
Young that leave nests with less reserves may face difficulties of survival in the first months of independence. Nestlings of S. biscutata loose $33.2 \%$ of weight in the first month after leaving the nest (Pichorim, 2002). It is probable that mortality of young is inversely associated to the weight that they have on leaving the nest. Thus, the investment in larger broods should only be done in ideal conditions, where fat reserves can be guaranteed permitting high survival indices after leaving nest, without jeopardizing the adults' survival. Nestlings of $C$. niger need to accumulate fat during nestling period, as they become independent immediately after leaving the nest and then have to face a long migratory journey (Marín, 1997). Nestlings of A. apus can accumulate fat as a prevention against variation in climatic conditions and food availability (Lack and Lack, 1951). Nestlings of A. apus and Apus pallidus (Shelley, 1870) in increased broods also show lower weight gain, and this can affect survival after leaving the nest (Martins and Wright, 1993; Cucco and Malacarne, 1996).

In short, nestlings of $S$. biscutata of experimental nests showed a development inversely associated to brood size, and considering that we did not find this explicit tendency in control nests, we can assume that the raising capacity of couples is associated to brood size. According to this hypothesis, couples with more nestlings are in better physical conditions than those with fewer nestlings. For this reason, the pattern of growth is similar in control broods of different sizes. However, when these couples are submitted to sudden changes in number of nestlings to be reared, as happened in experimental nests, then the growth pattern changes because they are under or overloaded during the raising. Thus, we concluded that couples have an optimal brood size that agrees with their physical conditions. A process of brood size regulation apparently exists, which seems to consist of expelling eggs during incubation.

The behaviour to eject eggs during incubation has already been reported for this species, as well as for other members of the family (Moreau, 1942; Lack and Lack, 1951; Medway, 1962, Snow, 1962; Rowley and Orr, 1962; Pellantová, 1975; Pichorim, 1998; Pichorim, 2002). Apus caffer (Lichtenstein, 1823) seems to expel eggs in function of climatic changes (Moreau, 1942). Apparently normal eggs of $A$. apus are thrown out, usually under bad climatic conditions, those eggs hatch when put in incubators, which discards the possibility of ejection due to infertility or embryo death (O'Connor, 1979). For A. apus, it has been speculated that the expelling of eggs is a result of nest site competition or a clutch size control manner, guaranteeing the optimum number of breed to be created (Koskimies, 1950; O'Connor, 1979). In view of these reports and the present study's results, it is probable that a large part of egg ejection in Apodidae is due to brood size control behaviour, and not to accidental falling down or to conflicts for nest sites. It is known however that in some species, such as Apus affinis (Gray, 1830), direct competition for nests exists and that this 
engenders egg destruction and rearrangement of couples (Hotta, 1994). The possibility of egg ejection due to nest site competition has been considered for S. biscutata too (Pichorim, 2002). But, in this species, the reposition of expelled eggs only happens in the beginning of the egg-laying period. Losses of eggs after incubation has started will lead to nest desertion and not to rearrangement of couples with new laying. Thus losses of eggs in $S$. biscutata are probably not related to competition, except for the beginning of the egg-laying period, and additional losses afterwards are probably linked to brood size control behaviour.

Lack and Lack (1951) affirm that clutch size in A. apus is adapted to the number of young that parents are able to feed, and Perrins (1964) reinforces this idea. With regard to Aerodramus maximus (Hume, 1878) and A. fuciphagus, it was suggested that clutch size is influenced basically by two factors: skill to feed the brood and prevention against unsuccessful reproduction caused by egg-laying above normal (Lee and Kang, 1994). Breeding success of $S$. biscutata is directly proportional to clutch size during incubation and inversely proportional to brood size during the nestling period (Pichorim, 2003). All this evidence suggests the probability of a selective pressure making clutch size compatible with brood throughout the species' entire reproductive period.

Acknowledgements - The first author thanks the Conselho Nacional de Desenvolvimento Científico e Tecnológico (CNPq) for having granted him a scholarship. We both thank the PostGraduation Course in Zoology of the Universidade Federal do Paraná for institutional support. The Instituto Ambiental do Paraná allowed access to the Parque Estadual de Vila Velha without which this study could not have been realised. We are grateful to Prof. James J. Roper for collaboration during our work. We also thank Alexandre Lorenzetto, Aline Dal'Maso Ferreira, Arthur A. Bispo de Oliveira, Juliano Ribeiro and Maximiliano Niedfeld for invaluable collaboration during field activities.

\section{References}

CHANTLER, P., 1999. Family Apodidae (Swifts). In DEL HOYO, J., ELLIOTT, A. and SARGATAL, J. (Eds.). Handbook of the Birds of the World, Barn-owls to Hummingbirds. Barcelona: Lynx Edicions. 759 p.

CHANTLER, P. and DRIESSENS, G., 1995. Swifts, a Guide to the Swifts and Treeswifts of the World. Sussex: Pica Press. 237 p.

CUCCO, M. and MALACARNE, G., 1996. Effect of food availability on nestling growth and fledging success in manipulated Pallid Swift broods. J. Zool., Lond., vol. 240, no. 2, p. 141-151.

DEXTER, RW., 1981. Nesting success of Chimney Swifts related to age and the number of adults at the nest, and the subsequent fate of the visitors. J. Field Ornithol., vol. 52, no. 3, p. 228-232.

HOTTA, M., 1994. Infanticide in little swifts taking over costly nest. Anim. Behav., vol. 47, no. 2, p. 491-493.

KOSKIMIES, J., 1950. The life of the swift, Micropus apus (L.), in relation to the weather. Ann. Acad. Sci. Fennicae, vol. A4, no. 15 , p. $1-151$.
LACK, D. and ARN, H., 1947. Die Bedeutung der Gelegerosse beim Alpensegler. Ornith. Beob., vol. 44, p. 188-210.

LACK, D. and LACK, E., 1951. The breeding biology of the swift Apus apus. Ibis, vol. 93, no. 4, p. 501-546.

LANGHAM, N., 1980. Breeding biology of the edible-nest swiftlet Aerodramus fuciphagus. Ibis, vol. 122, no. 4, p. 447-461.

LEE, PG. and KANG, N., 1994. The reproductive strategies of Edible-nest-swiftlets (Aerodramus spp.). Bull. B. O. C., vol. 114, no. 2, p. 106-113.

MAACK, R., 1968. Geografia Física do Estado do Paraná. Curitiba: BADESPA/UFPR/IBPT. $350 \mathrm{p}$.

MARÍN, M., 1997. Some aspects of the breeding biology of the Black Swift. Wilson Bull., vol. 109, no. 2, p. 290-306.

MARTINS, TLF. and WRIGHT, J., 1993. Brood reduction in response to manipulate brood sizes in the common swift (Apus apus). Behav. Ecol. Sociobiol., vol. 32, no. 1, p. 61-70.

MEDWAY, L., 1962. The swiftlets (Collocalia) of Niah Cave, Sarawak - Part I. breeding biology. Ibis, vol. 104, no. 1, p. 45-66.

MOREAU, RE., 1942. The breeding biology of Micropus caffer streubelli Hartlaub, the White-rumped swift. Ibis, vol. 84, no. 1, p. 27-49.

O'CONNOR, RJ., 1979. Egg weights and brood reduction in the European Swift (Apus apus). Condor, vol. 81, no. 2, p. 133-145.

PELLANTOVÁ, J., 1975. The course of breeding of the swift (Apus apus Linn.). Zool. Listy., vol. 24, no. 3, p. 249-262.

-, 1981, The growth of young of the swift, Apus apus, in relation to the number of nestlings, temperature, feeding frequency and quantity of food. Folia Zool., vol. 30, no. 1, p. 59-73.

PERRINS, CM., 1964. Survival of young swifts in relation to brood size. Nature, vol. 201, no. 4924, p. 1147-1148.

PICHORIM, M., 1998. Biologia reprodutiva do andorinhãode-coleira-falha, Streptoprocne biscutata (Sclater 1865) (Aves: Aapodidae) do Morro Anhangava, Serra do Mar Paranaense. Curitiba: Universidade Federal do Paraná. 67 p. [Dissertation Ms. C].

-, 2002, The breeding biology of the Biscutate Swift (Streptoprocne biscutata) in southern Brazil. Ornitologia Neotropical, vol. 13, no. 1 , p. 61-84.

-, 2003. Parâmetros populacionais de quatro colônias de Streptoprocne biscutata (Aves: Apodidae) do leste do Estado do Paraná, Sul do Brasil. Curitiba: Universidade Federal do Paraná. 146 p. [Doctorate Thesis].

ROWLEY, JS. and ORR, RT., 1962. The nesting of the Whitenaped swift. Condor, vol. 64, no. 5, p. 361-367.

SNOW, DW., 1962. Notes on the biology of some Trinidad Swifts. Zoologica, vol. 47, no. 12, p. 129-139.

TARBURTON, MK., 1987. An experimental manipulation of clutch and brood size of White-rumped Swiftlets Aerodramus spodiopygius of Fiji. Ibis, vol. 129, no. 1, p. 107-114.

VASCONCELOS, MF. and FERREIRA, JC., 2001. Sazonalidade e reprodução do andorinhão-de-coleira-falha (Streptoprocne biscutata) no Pico do Inficionado, Serra do Caraça, Minas Gerais, Brasil. Tangara, vol. 1, no. 2, p. 74-84.

ZAR, JH., 1984. Biostatistical Analysis. New Jersey: PrenticeHall. 736 p. 